\title{
Competition for Firms in an Oligopolistic Industry: The Impact of Economic Integration
}

\author{
Andreas Haufler* \\ University of Munich and CESifo \\ Ian Wooton \\ University of Strathclyde, CEPR and CESifo \\ Revised version, June 2009
}

\begin{abstract}
We set up a model of generalised oligopoly where two countries of different size compete for an exogenous, but variable, number of identical firms. The model combines a desire by national governments to attract internationally mobile firms with the existence of location rents that arise even in a symmetric equilibrium where firms are dispersed. As economic integration proceeds, equilibrium taxes initially decline, but then rise again as trade costs fall even further. A range of trade costs is identified where economic integration raises the welfare of the small country, but lowers welfare in the large country.
\end{abstract}

Keywords: tax/subsidy competition, oligopolistic markets, economic integration

JEL Classification: F15, F23, H25, H73

${ }^{*}$ Corresponding author. Seminar for Economic Policy, Akademiestr. 1/II, D-80799 Munich. Phone: +49-89-2180-3858, fax: +49-89-2180-6296, e-mail: Andreas.Haufler@lrz.uni-muenchen.de 


\section{Introduction}

The rise in foreign direct investment (FDI) and the increasing role played by large, multinational firms have been amongst the most important dimensions of the continuing globalization of the world economy over the past three decades. These developments have had profound effects on the attitude taken by governments towards the location of mobile firms in their jurisdictions. This is reflected in the policies governments have adopted in order to encourage investment by these firms.

One facet of this is the decline in corporate taxes as nations compete to attract investment. Table 1 shows that nominal and effective average rates of corporation tax have fallen significantly over the last two decades and this downward trend has been even more pronounced in small countries. Nevertheless, corporate tax rates remain substantial in large and small countries alike. Moreover, at least for the small countries the downward trend of tax rates seems to have slowed down during the period 1995-2005, as compared to the preceding decade. This offers some first indication that there may be a 'bottoming out' of tax rate competition as economic integration proceeds. ${ }^{1}$

****** Table 1 about here $* * * * * *$

Competition for mobile firms also arises through state aid for the location of new plants or the expansion of existing ones. Such investment subsidies have become commonplace, in particular in sectors that combine the use of modern technologies with the creation of new jobs. This is well documented in the European Union (EU), where state aid given by member states to individual enterprises in their jurisdiction must be approved by the European Commission. Table 2 lists 16 cases for the years 2001-2007 where investment subsidies in excess of Euro 40 million, and typically accounting for 10-

\footnotetext{
${ }^{1}$ Revenue from corporate taxation, as a percentage of GDP, has remained stable or even increased in most OECD countries during the last two decades (see OECD, 2007). Corporate tax revenue may not be a good indicator for the forces of tax competition, however, because it includes the effect of firms switching from unincorporated to incorporated businesses in order to take advantage of falling corporate tax rates. Recent empirical evidence shows that this effect may be substantial, raising corporate tax receipts at the expense of personal income tax revenue (see de Mooij and Nicodème, 2008). Nevertheless, the evidence on corporate tax collections underscores the point that profit taxation is not losing its importance. See Hines (2007) for a recent overview of these developments.
} 
$30 \%$ of the present value of the investment, have been approved. ${ }^{2}$ The recent apparent decline in the number of such subsidies may, however, be first evidence of a policy reversal in this area. In Germany, for example, an intensive debate on the justification of subsidies for increasingly mobile investments broke out in 2008, after Nokia had closed a mobile phone plant in Northrhine-Westphalia that had only been erected in the 1990s, with the help of state subsidies, and simultaneously opened up a new plant in Romania.

****** Table 2 about here $* * * * * *$

Finally, there are clear signs that increasing economic integration and the mobility of multinational firms have led to conflicting interests between large and small countries. During the last decade large countries, in particular, have found themselves under increasing pressure to cut tax rates, in order to avoid losing investment to their smaller, lower-tax neighbours (see Table 1). In the EU, for example, this has led to the adoption of a Code of Conduct for business taxation that was directed primarily at the special tax breaks being offered to multinational firms. This regulation caused a total number of 40 preferential tax regimes to be phased out, most of which had been applied by small EU countries (see Primarolo Report, 1999). ${ }^{3}$ At the same time the OECD (2000) launched a campaign against 'harmful tax policies', which was directed almost exclusively at small tax havens worldwide. Essentially these policy initiatives attempted to counteract the way in which small countries have taken advantage of an increased organizational flexibility in large, multinational firms.

In this paper we aim to contribute to the understanding of these simultaneous developments. For this purpose we set up a model that incorporates a desire on the part of national governments to attract internationally mobile firms, but also gives governments the ability to tax location rents earned by firms. Countries differ in the size of their respective population. Our focus is on the development of tax rates and the resulting welfare levels in small and large countries as economic integration proceeds.

\footnotetext{
${ }^{2}$ Davies (2005, Table 1) collects a similar list of investment subsidies granted by U.S. states.

${ }^{3}$ Examples of such preferential tax regimes were a split corporate tax rate regime in Ireland and special tax rules for multinational holding companies in the Benelux countries. Both of these measures were highly successful in attracting foreign direct investment.
} 
More specifically, we set up a model of generalised oligopoly in a region where two countries of different size use corporate taxes to compete for an exogenous, but variable, number of identical firms owned by residents of a third country. Our model features location rents for firms that arise even in a symmetric equilibrium. This is because, in the presence of trade costs, firms want to set up in different locations from one another in order to reduce the competitive pressures that they face and increase gross profits. This gives the host governments an opportunity to grab these rents through taxes. On the other hand, we assume that governments want to attract firms to their jurisdiction as consumers prefer locally produced goods to imports. Trade costs again drive this motivation. Local production is cheaper than importing goods and hence consumer prices are lower, and consumer surplus higher, when goods are made in the domestic market. ${ }^{4}$ Other things equal, this makes governments willing to subsidise inward foreign direct investment. The overall tax policies in our model thus derive from the combination of these two counteracting forces.

Our model delivers two main results. First, we find a $U$-shaped relationship between equilibrium tax rates and trade costs. Tax rates in both countries decline in the initial stages of economic integration but rise again when trade costs fall further. This pattern results as the relative strength of the two effects on tax policy described above changes in the course of economic integration. Second, we show that there is a range of trade costs where economic integration raises the welfare of the small country, but lowers welfare in the large country. This indicates that, at some stages of economic integration, there may indeed be conflicting interests between large and small countries with respect to continuing the process of market integration.

The analysis is related to two strands in the literature. A first set of papers focuses on the competition between potential host countries for a single multinational firm. In these models the equilibrium policy generally involves a location subsidy to the firm. Reasons why countries (or states) will want to attract firms include: scale economies

\footnotetext{
${ }^{4}$ Of course, increased consumer surplus is not the only potential benefit that might arise from local production. For example, perhaps the most persuasive argument for government investment subsidies is that multinational firms may offer a wage premium over domestic workers' outside options, an extreme case of which occurs when inward FDI relieves involuntary unemployment. We discuss this case in an extension of our model in section 5 .
} 
in the provision of public goods and services in conjunction with a mobile workforce (Black and Hoyt, 1989); positive spillovers from employment in the host jurisdiction (Haaparanta, 1996; Davies, 2005); savings in trade costs (Haufler and Wooton, 1999); or technological backwardness (Fumagalli, 2003). Recent work has shown, however, that these results change when an indigenous firm is already operating in one of the countries (Bjorvatn and Eckel, 2006) or when countries compete for two mobile firms, rather than one (Ferrett and Wooton, 2005). In the latter case, countries may even be able to tax away all profits in the non-cooperative tax equilibrium. A general feature of these models is that they involve the comparison of discrete equilibrium allocations and analyse specific scenarios that are difficult to compare or generalise.

A second literature strand has analysed tax competition for internationally mobile firms in models of the new economic geography (Kind et al., 2000; Baldwin and Krugman, 2004; Ottaviano and van Ypersele, 2005; Borck and Pflüger, 2006). These models employ a framework of monopolistic competition where otherwise identical firms produce different varieties of a composite good. ${ }^{5}$ This literature has stressed that agglomeration rents can be taxed, at positive levels, by the government of a "core country". However, this result applies only in the special case where all firms are agglomerated in one country, whereas subsidies are paid in equilibrium when firms are regionally dispersed. In contrast the present model focuses only on interior location equilibria and shows that positive tax rates can arise even if firms are fully dispersed in equilibrium.

Our analysis develops as follows. In section 2 we present the basic model. Section 3 analyses the non-cooperative tax equilibrium and the allocation of firms in the case where countries are symmetric and in the case where they differ in size. Section 4 derives the welfare effects of economic integration, again differentiating between the scenarios of symmetric and asymmetric countries. In section 5 we consider two extensions by incorporating an employment benefit from FDI and by allowing for local ownership of the active firms in the two competing countries. Section 6 concludes.

\footnotetext{
${ }^{5}$ For an extension that accounts for firm heterogeneity, see Burbidge et al. (2006). Another related analysis is Fuest (2005) who studies the implications for tax policy when economic integration reduces trade barriers but also increases the foreign ownership share of domestic firms.
} 


\section{The model}

\subsection{Consumers}

We consider a region with two countries $a$ and $b$, which compete to attract a fixed number of firms. These firms produce an homogeneous good, labelled $x$, in an oligopolistic industry. A second, private good, the numeraire commodity $z$, is produced under conditions of perfect competition. Consumers in both countries have identical preferences for the goods, given by

$$
u_{i}=\alpha x_{i}-\frac{\beta}{2} x_{i}^{2}+z_{i}, \quad i \in\{a, b\} .
$$

The two countries potentially differ in size. The population of the region is normalised to unity and, without loss of generality, we take country $a$ to be the larger of the two. Let there be $n \geq 0.5$ consumers in country $a$ and $(1-n)$ consumers in country $b$. The residents of countries $a$ and $b$ earn only wage income, while profit income accrues to capital owners that reside in a third (outside) country. ${ }^{6}$ Every household in the region supplies a single unit of labour. The wage rate in each country is determined in the numeraire industry, which uses labour as the only input. Free trade in the numeraire good therefore equalises the wage across the countries as $w$. Moreover, total income from the business tax (as detailed below), denoted by $T_{i}$, is redistributed equally and in a lump-sum fashion to the consumers in each country. The budget constraint for a representative consumer in each of the two countries is then

$$
w+\frac{T_{a}}{n}=z_{a}+p_{a} x_{a}, \quad w+\frac{T_{b}}{1-n}=z_{b}+p_{b} x_{b},
$$

where $p_{i}$ is the price of good $x$ in country $i$. Utility maximisation leads to inversedemand curves $\alpha-\beta x_{i}=p_{i}, \forall i$. Aggregating the demand for good $x$ over all consumers yields market demand curves for each country, denoted $X_{i}$ :

$$
X_{a}=\frac{n\left(\alpha-p_{a}\right)}{\beta}, \quad X_{b}=\frac{(1-n)\left(\alpha-p_{b}\right)}{\beta} .
$$

When $n>0.5$, the market demand curve of the larger country $a$ is flatter than that of country $b$. In this sense market $a$ is the more profitable one for firms, as we shall see below.

\footnotetext{
${ }^{6}$ In section 5 we discuss the case where profit income accrues to the residents of countries $a$ and $b$.
} 


\section{$2.2 \quad$ Firms}

There are $k$ firms in total, based in a third country and prepared to invest in the region. Each of these firms possesses one unit of "knowledge capital" (such as a license or patent) that can be profitably employed in the imperfectly competitive industry $x$. This factor is indispensable for the production of good $x$ but limited in availability such that, at most, $k$ firms can engage in production. In addition, each firm faces fixed and identical costs of setting up a production facility in each of the two countries. These costs are assumed to be sufficiently large to ensure that each firm will set up, at most, one production plant in the region. Thus each firm will serve the regional market from either country $a$ or country $b{ }^{7}$ Firms are assumed to be identical except with respect to the location of their production facilities. Location matters because, while all firms can sell their products in both countries, there are trade costs associated with exports to a firm's foreign market. Thus each country's market may be served by both "local" firms that produce domestically and "foreign" firms that are based in the other country.

Labour is the only variable input in good $x$ production. Each unit of good $x$ requires the efforts of $\gamma$ workers, where $\gamma$ is chosen so that production of $x$ does not exhaust each country's labour supply. Hence the marginal cost of production can be defined as $\omega \equiv \gamma w$. Since wage costs are equalised between the two countries, they do not enter the location decision of firms in our model. The cost of exporting each unit of output is $\tau$, which effectively raises the marginal cost of serving the foreign market to $(\omega+\tau)$. We are assuming that all of the trade costs are "real", taking the form of, say, transport costs or administrative barriers to the free movement of goods between countries. There are no (endogenously determined) tariffs between countries $a$ and $b$ as we assume that the region is a free-trade-area.

Firms are assumed to behave as Cournot competitors and are able to segment their markets, choosing the quantities to sell on their domestic and export markets indepen-

\footnotetext{
${ }^{7}$ If trade costs were sufficiently high relative to these fixed costs, the firm might choose to "jump" the trade barrier and produce in both markets. We assume that this is not the case. We further assume that the trade costs between the region and the rest of the world are sufficiently high that no firm would choose to service the markets of $a$ and $b$ from a third country outside the region. For notational simplicity the fixed costs are suppressed in the equations below.
} 
dently. ${ }^{8}$ The total operating profit of each firm, which equals the return to the required unit of knowledge capital, is thus defined as

$$
\begin{aligned}
& \pi_{a}=\left(p_{a}-\omega\right) x_{a a}+\left(p_{b}-\omega-\tau\right) x_{b a}, \\
& \pi_{b}=\left(p_{a}-\omega-\tau\right) x_{a b}+\left(p_{b}-\omega\right) x_{b b}
\end{aligned}
$$

where $\pi_{j}$ is the pre-tax profit of a firm based in country $j$ and $x_{i j}$ represents sales in country $i$ by a firm based in country $j(i, j \in\{a, b\})$. A firm is at a cost disadvantage in its export market as the marginal cost of exports is higher than that for domestic sales. Consequently an exporter will sell less in a market than an indigenous rival.

Suppose that $k_{a}$ firms are located in country $a$ and the remaining $k_{b}$ firms produce in country $b$, where $k_{a}+k_{b}=k$. Maximising (4) taking into account demand (3), yields output levels per firm:

$$
\begin{array}{llrl}
x_{a a} & =\frac{n\left[\alpha-\omega+k_{b} \tau\right]}{\beta(k+1)} ; & x_{b a} & =\frac{(1-n)\left[\alpha-\omega-\left(1+k_{b}\right) \tau\right]}{\beta(k+1)} ; \\
x_{a b}=\frac{n\left[\alpha-\omega-\left(1+k_{a}\right) \tau\right]}{\beta(k+1)} ; & x_{b b}=\frac{(1-n)\left[\alpha-\omega+k_{a} \tau\right]}{\beta(k+1)} .
\end{array}
$$

We focus on the cases where the trade cost is sufficiently low to ensure that $x_{a b}>$ $0, x_{b a}>0$ and each firm exports into the foreign country's market. From (5) and in the symmetric situation, where the host countries are the same size $(n=0.5)$ and each attracts the same number of firms $\left(k_{a}=k_{b}\right)$, both countries will export if

$$
\alpha-\omega-\left(1+\frac{k}{2}\right) \tau>0
$$

We assume throughout the following analysis that this condition is met. ${ }^{9}$ This constraint implies that trade costs remain below a critical upper limit, beyond which firms will only serve their domestic markets. For the symmetric case this prohibitive trade cost is

$$
\tau^{P}=\frac{2(\alpha-\omega)}{2+k}
$$

${ }^{8}$ In equilibrium, firms will receive a lower producer price for their exports than for goods destined for the domestic market. The trade structure is simply a generalisation of the "reciprocal dumping" model of Brander and Krugman (1983).

${ }^{9}$ Note that (6) is also a necessary (but not a sufficient) condition for exports to occur into both markets when countries differ in size and $k_{a} \neq k_{b}$. In this case it is seen from (5) that one of the conditions for $x_{a b}>0, x_{b a}>0$ will involve an even tighter constraint on $\tau$. 
We further assume that the resource constraints $\gamma k_{a}\left(x_{a a}+x_{b a}\right)<n$ and $\gamma k_{b}\left(x_{a b}+x_{b b}\right)<$ $(1-n)$ are met and that the numeraire good is produced in each country. Observe that $x_{a b} / x_{a a}, x_{b a} / x_{b b}<1$, confirming our assertion that a foreign firm's share of a market is always less than that of a local firm whenever there are trade costs $(\tau>0)$. Equilibrium prices in each market are:

$$
p_{a}=\frac{\alpha+k \omega+k_{b} \tau}{k+1} ; \quad p_{b}=\frac{\alpha+k \omega+k_{a} \tau}{k+1} .
$$

Notice that consumer prices in both countries fall when the total number of firms $k$ increases and competition in the oligopolistic industry is thereby intensified. Moreover, in each country the consumer price is a rising function of the number of active firms in the other country. In other words, whatever the size of the industry, having more firms producing locally intensifies domestic competition and drives down consumer prices.

Substituting (5) and (8) into (4) yields the pre-tax profits of firms in each country:

$$
\begin{aligned}
& \pi_{a}=\frac{n\left[\alpha-\omega+k_{b} \tau\right]^{2}}{\beta(k+1)^{2}}+\frac{(1-n)\left[\alpha-\omega-\left(1+k_{b}\right) \tau\right]^{2}}{\beta(k+1)^{2}} \\
& \pi_{b}=\frac{n\left[\alpha-\omega-\left(1+k_{a}\right) \tau\right]^{2}}{\beta(k+1)^{2}}+\frac{(1-n)\left[\alpha-\omega+k_{a} \tau\right]^{2}}{\beta(k+1)^{2}} .
\end{aligned}
$$

We assume that profits are taxed at source by the host countries of the firms. ${ }^{10}$ Let $t_{i}$ be the lump-sum tax imposed on each firm by country $i$. Then total tax revenues are

$$
T_{i}=t_{i} k_{i} \quad \forall i \in\{a, b\}
$$

The tax differential between countries is $\Delta \equiv t_{a}-t_{b}$. In deciding upon where to invest, firms will compare profits net of taxes and locate in the more profitable country. The locational equilibrium for the industry is characterised by $\pi_{a}-t_{a}=\pi_{b}-t_{b}$. Substituting (9) gives the equilibrium number of firms choosing to locate in each country:

$$
k_{a}=\frac{k}{2}+\frac{(2 n-1)[2(\alpha-\omega)-\tau]}{2 \tau}-\frac{\Delta \beta(k+1)}{2 \tau^{2}} ; \quad k_{b}=k-k_{a}
$$

\footnotetext{
${ }^{10}$ There is an agreement in the literature that international company taxation closely follows the source principle (Tanzi, 1995, Ch. 6-7). This principle applies directly, if countries avoid international double taxation by exempting foreign-earned income from domestic tax. If countries grant an international tax credit instead, source taxation is still effective in many cases, because crediting applies only after profits have been repatriated and because countries do not rebate 'excess' taxes paid abroad.
} 
Suppose, initially, that each country charges the same tax, that is $\Delta=0$. If the countries were the same size $(n=0.5)$, it is clear from (11) that $k_{a}=k_{b}=k / 2$, that is, the firms would be evenly split between the two locations. In the absence of trade costs, neither country has a locational advantage and $k_{a}$ is undefined. When $\tau>0$ and country $a$ is relatively large $(n>0.5)$, the second term in (11) is unambiguously positive due to the constraint (6). Differences in taxes will further affect the location of firms such that, if country $a$ taxes firms more heavily than country $b$ (that is, $\Delta>0$ ), country $a$ 's share of the firms will be relatively smaller than it would otherwise be. However, as will be shown in section 3.2, the third term can never fully compensate the second and so the larger country will attract more than half of all firms in any asymmetric tax equilibrium [cf. eq. (20) below]. ${ }^{11}$

\subsection{Governments}

The governments of countries $a$ and $b$ each impose lump-sum taxes on firms that locate within their respective jurisdictions. Importantly, these taxes can be negative, acting as subsidies to attract investment to a particular country. If revenues from the business tax are positive, then these are redistributed equally and in a lump-sum way to the residents in the country in which they are collected. The costs of a negative business tax are raised through lump-sum taxation of consumers. Recall that, despite their lump-sum character, business taxes still distort the location decision of internationally mobile firms [eq. (11)]. ${ }^{12}$

Governments maximise the welfare of their representative consumers. To derive aggregate welfare in each country, we use the budget constraint (2) to substitute out for the consumption of the numeraire good $z_{i}$ in the individuals' utility function (1)

\footnotetext{
${ }^{11}$ Our analysis treats $k_{a}$ and $k_{b}$ as continuous variables. Hence we only approximate the "true" model when the number of firms is small and the relocation of a single firm has discrete implications for the equilibrium allocation. Alternatively, we can conceptually introduce stochastic location decisions of firms and interpret $k_{a}$ and $k_{b}$ as the expected number of firms in each country. The main advantage of this procedure is that we can derive equilibrium allocations and policies as continuous functions of exogenous model parameters.

${ }^{12}$ Introducing an ad valorem profit tax instead of a lump-sum tax on firms would complicate the algebra, but it would cause no further distortions and hence would not change our qualitative results.
} 
and employ the inverse demands to eliminate $p_{i}$. Further employing $x_{a}=X_{a} / n$ and $x_{b}=X_{b} /(1-n)$, using the equilibrium prices from (8) in the market demand functions (3) and aggregating over consumers yields:

$$
W_{a}=n u_{a}=S_{a}+T_{a}+n w, \quad W_{b}=(1-n) u_{b}=S_{b}+T_{b}+(1-n) w,
$$

where $S_{i}$ is country $i$ 's total consumer surplus in market $x$ :

$$
S_{a}=\frac{n\left[k(\alpha-\omega)-k_{b} \tau\right]^{2}}{2 \beta(k+1)^{2}}, \quad S_{b}=\frac{(1-n)\left[k(\alpha-\omega)-k_{a} \tau\right]^{2}}{2 \beta(k+1)^{2}} .
$$

Hence, given our specification of individual utilities, national welfare can be expressed as the sum of aggregate consumer surplus in market $x$, and the money income of all consumers (the sum of wage income and tax revenue). ${ }^{13}$ Consumer surplus in each country is rising in the total number of firms $k$, as this intensifies competition and reduces producer prices in both countries [cf. eq. (8)]. Moreover, a rise in the share of firms located in country $a$ raises consumer surplus in that country but lowers it in country $b$ because consumer prices are lower when more firms produce locally. This gives each nation an incentive to attract firms to its home jurisdiction. ${ }^{14}$

\section{Equilibrium taxes and location}

\subsection{Benchmark: Symmetric countries}

We substitute (10), (11) and (13) in (12) and differentiate each country's welfare expression with respect to its own tax. We first turn to the benchmark case where countries are identical in all respects. Hence we evaluate the first-order condition for the optimal tax rates at $n=0.5$ and substitute the equilibrium allocation of firms (11), again using this restriction. This yields closed-form solutions for the common Nash equilibrium tax

\footnotetext{
${ }^{13}$ Note that the wage income terms in (12) are constants and will thus not affect any of our results.

${ }^{14}$ Clearly, savings in transportation cost are only one (analytically convenient) example of why governments may want to attract internationally mobile firms. This motive could, for example, be replaced by wage earnings that exceed workers' outside options, or by technological linkages that exist between the oligopolistic industry $x$ and the production of the numeraire good $z$. We will discuss these alternative settings in section 5 .
} 
rate:

$$
t^{s}=\frac{k \tau}{(k+1) \beta}\left[\tau-\frac{2(\alpha-\omega)-\tau}{4(k+1)}\right],
$$

where the superscript $s$ stands for the symmetric case. These equilibrium tax rates reflect two fundamental effects that are at work in the present model.

The positive first term in the square brackets arises from a location-rent effect. This effect arises because firms want to locate in different markets, in order to minimise competition between them. Intuitively, starting from a symmetric equilibrium and moving one firm from country $b$ to country $a$ implies that each firm in country $a$ now faces more intense competition in its home market. Since a firm's home market is relatively more profitable than its export market, the gross profits of each firm in $a$ fall, whereas the gross profits of each firm that remains in $b$ rise. This profit differential implies that a location rent arises for each firm even in a fully symmetric equilibrium, and this rent can be taxed by the host government. ${ }^{15}$ This location-rent effect becomes stronger with higher trade costs, as these increase the difference in profitability between the home and the foreign markets.

The second term in the square brackets of (14) is the source of a consumer-price effect, which is unambiguously negative from (6). When an additional firm enters a country, consumer prices fall and, as discussed above, this provides each country with an incentive to offer location subsidies to firms.

From (14) we can determine the critical level of trade $\operatorname{costs} \tau^{*}$ at which the two effects just offset one another such that equilibrium taxes are zero:

$$
\tau^{*}=\frac{2(\alpha-\omega)}{4(k+1)+1}
$$

For trade $\operatorname{costs} \tau>\tau^{*}$ the location-rent effect dominates and equilibrium tax rates are positive, whereas for $\tau<\tau^{*}$ the consumer price effect is relatively stronger and equilibrium taxes are negative (that is, subsidies are given). Finally, neither effect has any impact in the absence of trade costs $(\tau=0)$. In this case of costless trade, the Nash equilibrium taxes are zero as both governments and firms are indifferent to the

\footnotetext{
${ }^{15}$ Algebraically, this effect can be shown by differentiating the gross profits that each firm earns in a symmetric equilibrium [eq. (9)] with respect to $k_{i}$. The resulting profit differential between a firm that is located in country $b$ and one that is located in $a$ is just equal to the first term in (14).
} 
equilibrium pattern of firm location. ${ }^{16}$

It should be noted that governments are constrained in their ability to tax, as post-tax profits must remain non-negative for all $k$ firms, otherwise some of the firms would choose not to produce. To derive this constraint, we subtract the tax rate in the symmetric Nash equilibrium (14) from a firm's pre-tax profits (9). Setting the difference equal to zero yields a critical value of trade costs $\bar{\tau}:{ }^{17}$

$$
\bar{\tau}=\frac{(\alpha-\omega)\left[k-2+\sqrt{13 k^{2}+8 k-4}\right]}{\left(3 k^{2}+3 k-2\right)} .
$$

Equation (16) defines a negative relationship between the total number of firms in the market and the critical (maximum) level of trade costs $\bar{\tau}$. Intuitively, a large number of firms $k$ reduces the gross profits that can be earned by each firm in equilibrium, whereas a high level of $\tau$ increases the ability of a country to set high taxes. Only if $\tau \leq \bar{\tau}$, will all $k$ firms be prepared to enter and produce in the region. We assume that this condition is met throughout our analysis. ${ }^{18}$

Comparing the critical value in (16) with the prohibitive trade cost determined in (7) shows that $\bar{\tau} \leq \tau^{P}$ for all $k \geq 2$. Hence, for most levels of $k$, eq. (16) is the binding constraint in our symmetric model. When this constraint is met and all $k$ firms make non-negative after-tax profits, then there will also be trade in equilibrium.

How are the symmetric Nash equilibrium tax rates affected by changes in the exogenous parameters of the model? Consider first an increase in the total number of mobile firms in the economy. Differentiating (14) with respect to $k$ yields

$$
\frac{\partial t^{s}}{\partial k}=\frac{\tau\{4 \tau(k+1)+(k-1)[2(\alpha-\omega)-\tau]\}}{4(k+1)^{3} \beta}>0
$$

and thus an increase in $k$ unambiguously raises equilibrium tax rates. Intuitively, a rise in the total number of firms lowers the costs that are perceived by each country

\footnotetext{
${ }^{16}$ This special case is related to the analysis by Janeba (1998), who introduces firm mobility to the standard model of strategic tax policy but does not include transport costs. He shows that equilibrium trade taxes will then be zero in both countries, in contrast to the trade subsidies that result in the absence of firm mobility (and with Cournot competition of firms).

${ }^{17}$ More precisely, this critical value represents an upper bound on trade costs, as we have ignored the fixed costs of locating in either country (see footnote 7). If these costs are explicitly incorporated, the maximum permissible tax rate, and hence the threshold value $\bar{\tau}$, are accordingly lower.

${ }^{18}$ It is easily checked that the level $\tau^{*}$, at which tax rates switch signs [eq. (15)], is below the threshold level $\bar{\tau}$. Hence there is a range of transport costs for which positive equilibrium taxes result.
} 
from losing one of the firms to the other country. The decline in the consumer-price effect reduces the willingness of each country to grant location subsidies. Moreover the larger number of firms strengthens the positive location-rent effect. The stronger is competition, and hence the closer prices are to marginal costs, the more severe is the disadvantage of having to bear extra trade costs. Hence, starting from a symmetric equilibrium, the penalty rises for a firm that attempts to escape high domestic taxes by moving abroad, and this strengthens the ability of each country to tax location rents. The comparative static result (17) makes it immediately clear that countries will not find it in their interest to reduce the total number of active firms in equilibrium. Since each country's tax rate is rising in $k$, so must be tax revenue. Moreover, consumer surplus [eq. (13)] is clearly a positive function of $k$. Hence welfare in each country [eq. 12] is monotonously increasing in the number of active firms. ${ }^{19}$

Our main interest lies on the effects of changes in trade costs. Differentiating (14) with respect to $\tau$ gives

$$
\frac{\partial t^{s}}{\partial \tau}=\frac{k[4 \tau(k+1)-(\alpha-\omega-\tau)]}{2(k+1)^{2} \beta},
$$

which may be positive or negative, in general. However, we can determine a critical threshold value for $\tau$ for which this derivative is zero. This is

$$
\tau^{* *}=\frac{\alpha-\omega}{4(k+1)+1} .
$$

For $\tau>\tau^{* *}$, the tax rate is rising in trade costs, whereas for $\tau<\tau^{* *}$ it is falling in $\tau$. Moreover, comparing (18) with (15) shows that $\tau^{* *}<\tau^{*} / 2$.

$$
\text { ****** Figure } 1 \text { about here } * * * * * *
$$

The relationship between the level of trade costs and the equilibrium tax rates in the symmetric Nash equilibrium is then as shown in Figure 1. We interpret economic integration as an exogenous reduction in trade frictions. The figure shows that, starting from high levels of trade costs $\left(\tau>\tau^{*}\right)$, a fall in these costs will reduce the ability of symmetric countries to raise positive business taxes. Below $\tau^{*}$ taxes turn negative and

\footnotetext{
${ }^{19}$ This effect underlies the different results in models where two countries compete for a single monopolist and pay subsidies in equilibrium, and those where they compete for two mobile firms and are able to levy positive taxes (see Ferrett and Wooton, 2005). Our analysis show that this effect holds more generally, and also applies to continuous increases in the number of firms.
} 
continue to fall until they reach a minimum (i.e., a maximum subsidy) at $\tau^{* *}$. To explain this negative relationship for relatively high levels of trade costs, note that the location-rent effect and the consumer price effect are both weakened when trade costs are reduced. However, the ability of countries to extract location rents falls more quickly as long as $\tau>\tau^{* *}$. If trade costs fall still further $\left(\tau<\tau^{* *}\right)$, the relative strength of the location-rent and consumer-price effects is reversed and tax rates rise again until they reach zero at $\tau=0$. Our results for the symmetric benchmark are summarised in:

Proposition 1 In the symmetric Nash equilibrium tax rates can be either positive or negative. As economic integration proceeds (trade costs are continuously reduced), equilibrium tax rates fall from positive to negative levels and then rise again, equalling zero when trade costs are eliminated.

\subsection{Differences in country size}

Having discussed the basic working of our model under symmetry, we now turn to the more general case where countries differ in size. We obtain closed-form solutions for the asymmetric Nash equilibrium tax rates, which are derived in the appendix:

$$
\begin{aligned}
& t_{a}^{*}=\frac{k \tau}{\beta(k+1)}\left[\tau-\frac{n \mu}{2(k+1)}\right]+\frac{\tau \mu(2 n-1)(3 k+2)[2(k+1)-n]}{2 \beta(k+1)^{2}[6(k+1)-1]}, \\
& t_{b}^{*}=\frac{k \tau}{\beta(k+1)}\left[\tau-\frac{n \mu}{2(k+1)}\right]-\frac{\tau \mu(2 n-1)[2(k+1)+n(3 k+2)]}{2 \beta(k+1)^{2}[6(k+1)-1]},
\end{aligned}
$$

where $\mu \equiv[2(\alpha-\omega)-\tau]>0$.

The first term in (19) is identical for both countries and captures the counteracting location-rent and consumer-price effects that have been discussed above. ${ }^{20}$ The second terms in (19) show how the overall bargaining position of countries vis-à-vis individual firms is modified by an additional home-market effect. Each firm will save aggregate trade costs and thereby make higher gross profits when it locates in the larger country. This allows the larger country $a$ to impose a higher tax than in the symmetric equilibrium, whereas the smaller country $b$ has to compensate firms for its location disadvantage by offering a lower tax (or a higher subsidy). Hence the larger country levies the higher tax rate in equilibrium for any positive level of trade costs.

\footnotetext{
${ }^{20}$ It is easily checked that the first terms in (19) reduce to eq. (14) for the symmetric case $n=0.5$.
} 
Our analysis focuses again on the effects of falling trade costs. We first turn to the question of whether economic integration will increase or decrease the concentration of firms in the larger country. This is determined by substituting the optimal tax rates in (19) into equation (11), yielding

$$
k_{a}=\frac{k}{2}+\frac{(2 n-1)[2(\alpha-\omega)-\tau]}{2 \tau} \frac{[3(k+1)-1]}{[6(k+1)-1]} .
$$

Differentiating (20) with respect to $\tau$ gives:

$$
\frac{\partial k_{a}}{\partial \tau}=\frac{-(2 n-1)[3(k+1)-1]}{2 \tau[6(k+1)-1]}\left\{1+\frac{[2(\alpha-\omega)-\tau]}{\tau}\right\}<0 .
$$

Hence a fall in trade costs unambiguously increases the number of firms in the larger country $a$. On the one hand, lower trade costs reduce the disadvantage that a firm has from settling in the smaller market. There is a second effect, however, which is dominating in our analysis. Trade costs shield the firms that locate in one market from the competition of firms that have located in the other. As trade costs fall, the competitive pressure rises relatively more in the small country $b$, because a larger number of firms (those in a) become closer competitors. In sum, therefore, market integration increases the concentration of production activity in the larger market $a$. Equation (20) also implies that a threshold level of trade costs, denoted $\underline{\tau}$, must be exceeded in order to ensure that a positive number of firms locates in the small country $b$ (i.e., $k_{a}<k$ ). This lower bound for $\tau$ in the presence of size asymmetries is given by

$$
\underline{\tau}=\frac{2(\alpha-\omega)(2 n-1)[3(k+1)-1]}{k[6(k+1)-1]+(2 n-1)[3(k+1)-1]} .
$$

The lower bound $\underline{\tau}$ is zero in the case of symmetric countries and it rises as the size differential between countries $a$ and $b$ increases. In other words, if low levels of trade costs (and thus a high degree of economic integration) are to be considered in our model, then the size asymmetries between the two countries must not be "too large". Next we consider the effects of economic integration on the tax rates imposed by each country in the asymmetric tax equilibrium. Differentiating (19) with respect to $\tau$ and re-substituting the tax rates in the initial equilibrium yields:

$$
\frac{\partial t_{i}^{*}}{\partial \tau}=\frac{2\left[(\alpha-\omega-\tau) t_{i}^{*}+(\alpha-\omega)\right]}{\tau[2(\alpha-\omega)-\tau]} \quad \forall i \in\{a, b\} .
$$

Hence, for either of the two countries, a positive tax rate in the initial equilibrium is sufficient (but not necessary) to ensure that a fall in trade costs reduces the optimal 
tax rate. This result parallels that for symmetric countries. However, from (19), the critical level of trade costs at which the large country's tax rate turns positive is now reduced relative to the symmetric case, whereas the critical level of trade costs at which the small country is able to levy positive taxes is increased. The relationship between trade costs and tax rates in the two countries is then as shown in Figure 2. ${ }^{21}$

****** Figure 2 about here $* * * * * *$

Our results for the case of asymmetric countries are summarised in:

Proposition 2 Consider two countries that differ only in size. As trade costs fall, (i) tax rates in both countries first fall and then rise again, with the larger country imposing the higher tax rate at each level of $\tau$; (ii) the concentration of firms in the larger country increases.

\section{Economic integration and national welfare}

We now turn to the welfare effects of economic integration and start again with the benchmark case of symmetric countries. Substituting (10), (13) and (14) in (12) and setting $k_{a}=k_{b}=k / 2$ yields the maximised welfare for each country

$$
W^{s}=\frac{k^{2}}{8 \beta(k+1)^{2}}\left\{[2(\alpha-\omega)-\tau]^{2}+2 \tau^{2}[4(k+1)+1]-4 \tau(\alpha-\omega)\right\}+\frac{w}{2} .
$$

Differentiating with respect to $\tau$ yields

$$
\frac{\partial W^{s}}{\partial \tau}=\frac{k^{2}}{16 \beta(k+1)^{2}}\{[8(k+1)+3] \tau-4(\alpha-\omega)\} .
$$

For high levels of trade costs, economic integration (a fall in $\tau$ ) is welfare-reducing for both countries; while for low trade costs, a further reduction is instead welfareincreasing. The critical value of trade costs where welfare reaches a minimum is obtained by setting $\partial W^{s} / \partial \tau$ in (24) equal to zero. This critical value $\tilde{\tau}$ is:

$$
\tilde{\tau}=\frac{4(\alpha-\omega)}{[8(k+1)+3]} .
$$

\footnotetext{
${ }^{21}$ To simplify the graph, Figure 2 ignores the fact that the maximum levels of trade costs that are compatible with non-negative profits $(\bar{\tau})$ will generally differ for the two countries.
} 
This $U$-shaped relationship between national welfare and trade costs closely mirrors the relationship between equilibrium tax rates and trade costs. At high levels of trade costs, a reduction in these costs weakens the location-rent effect, reducing the taxing power of governments and lowering both tax revenue and welfare. ${ }^{22}$ At low levels of $\tau$, a further fall in trade costs reduces the gains for each country from granting location subsidies to firms. This alleviates subsidy competition and increases each country's welfare. Comparing the critical level $\tilde{\tau}$ to the level of trade costs that induces the minimum tax $\tau^{* *}$ [see eq. (18)], shows that $\tilde{\tau}>\tau^{* *}$. Thus, as trade costs fall below $\tilde{\tau}$, tax rates continue to decline for some range of trade costs to the left of $\tilde{\tau}$ while welfare starts to climb again. The increase in welfare is explained by the fact that the falling tax revenues (alternatively, the increasing subsidy payments) are more than compensated by the rise in consumer surplus associated with the reduction in trade costs.

To analyse the effects on national welfare when countries differ in size, we substitute (11), (13) and (19) in (12). At low levels of economic integration, equilibrium taxes are positive in both countries and a reduction in $\tau$ will cause taxes and welfare to fall. However the welfare-minimizing levels of $\tau$ will differ for the large and the small country. Given that welfare in each country is a non-monotonic function of trade costs, there is the possibility that economic integration will have the opposite welfare effect in each country over a certain range of $\tau$. In particular, it can be shown that this is the case when the trade cost is equal to $\tilde{\tau}$, as defined in (25). At this level of trade costs (and, from continuity, in the neighbourhood of this value), the following holds:

$$
\left.\frac{\partial W_{a}}{\partial \tau}\right|_{\tilde{\tau}}>0,\left.\quad \frac{\partial W_{b}}{\partial \tau}\right|_{\tilde{\tau}}<0 .
$$

This leads to:

Proposition 3 There is a range of trade costs for which economic integration (a fall in $\tau$ ) reduces welfare in the larger country but increases welfare in the smaller country. Proof: See the appendix.

\footnotetext{
${ }^{22}$ This result implies that countries would have an interest in restricting trade in the early stages of economic integration. We assume, however, that countries regard the level of trade costs as strictly exogenous, the path of economic integration having been predetermined by, say, multilateral trade negotiations or "single-market" treaty obligations.
} 
Proposition 3 is explained from the fact that both the location-rent effect and the consumer-price effect are weaker for the small country. The smaller country is the less attractive location from the perspective of firms, but it also has fewer consumers and therefore has a smaller incentive to grant location subsidies. For this reason, country $b$ 's welfare level $W_{b}$ reaches its minimum at a higher level of trade costs as compared to $W_{a}$. As trade costs fall below this minimum of $W_{b}$, economic integration is beneficial for the small country, but still detrimental for welfare in the large country $a$.

Figure 3 illustrates these results. In the graph, economic integration has opposing welfare effects on the two countries if trade costs are in the range $\tau_{a}<\tau<\tau_{b}$, where $\tau_{i}$ is the turning point of $W_{i}$ with respect to $\tau$.

****** Figure 3 about here $* * * * * *$

Finally, we illustrate the results of our basic model by means of a simulation analysis, where we assume that $n=0.6$. The results are summarised in Table 3 .

****** Table 3 about here $* * * * * *$

In this particular numerical example the upper limit of trade costs that still ensures non-negative after-tax profits is $\bar{\tau} \approx 0.68$, whereas the lower limit for $\tau$ that ensures a non-negative number of firms in the smaller country is $\underline{\tau} \approx 0.10$. Columns (1) and (2) show that $t_{a}>t_{b}$ holds for all levels of trade costs [Proposition 2(i)] and country $b$ 's tax rate turns negative at a higher level of trade costs than that of country $a$. In columns (3) and (4) tax rates are calculated as a percentage of gross profits. This ratio approaches unity in both countries at $\bar{\tau}$. As is seen in column (5) this ratio initially declines more steeply in the smaller country as trade costs are reduced, but then the tax difference shrinks again. Column (6) shows that the number of firms in country $a$ rises continuously as trade costs fall [Proposition 2(ii)]. Finally, columns (7) and (8) give the per-capita welfare level in each country. Comparing these two columns for any given level of $\tau$ shows that welfare is always higher in the larger country, which hosts a larger number of firms and thus benefits from both lower transport costs and stronger competition in its market. ${ }^{23}$ For changing levels of $\tau$, these results confirm that there

\footnotetext{
${ }^{23}$ There is an interesting contrast here to the literature analysing tax competition between countries
} 
is a range of trade costs $\tau \in(0.15,0.25)$ where a small reduction in $\tau$ lowers welfare in country $a$, but raises welfare in country $b$ (Proposition 3).

These results of our model are roughly consistent with the patterns of corporate tax adjustments in large and small countries, as given in Table 1. This table shows that in 1985, at the onset of economic integration, tax rates were at a "maximum" level that was similar for large and small countries. In the early phases of economic integration, tax rates fell more in the small countries, leading to a substantial tax gap between large and small countries by 1995. As economic integration continued, the large countries also cut their tax rates and the tax gap between large and small countries narrowed during the period 1995-2005. As is shown in column (5) of Table 3, the initial widening and later narrowing of this tax gap is captured by our model, if (analytically more convenient) lump-sum taxes on each firm are transformed into ad valorem profit taxes. Finally, even though there are many differences between our model and those used in the new economic geography (NEG) literature, it is interesting to point out some of the contrasting implications. A core difference is that positive tax rates are possible in our model even in a fully symmetric equilibrium, whereas equilibrium tax rates are always negative in NEG models when firms are regionally dispersed in the locational equilibrium (Ottaviano and van Ypersele, 2005). ${ }^{24}$ Moreover, if all firms are concentrated in one of the countries, the optimal tax rate of the country hosting the agglomeration is an inversely $U$-shaped function of trade costs, whereas it is $U$-shaped in our analysis. These differences can be traced back to the existence of a location-rent effect in our model, which arises because firms make positive profits in equilibrium. In contrast, NEG models typically assume endogenous market entry which drives each firm's profit to zero. Hence no taxable location rent arises in either country and the location-rent effect accordingly disappears.

of different size in models of perfectly competitive factor and product markets (Bucovetsky, 1991; Wilson, 1991). As in our analysis, this literature finds that the smaller country levies the lower capital tax rate. However, due to the absence of either location or competitive effects in these analyses, the small country attains a higher level of per-capita utility than its larger neighbour, because its lower tax rate leads to a higher capital-labour ratio in equilibrium.

${ }^{24}$ See their Proposition 3. Note that there is an error in part ( $\left.i\right)$ of this proposition. In the case where countries are equal-sized, equilibrium tax rates will be negative (and not zero) in both countries. We thank Tanguy van Ypersele for clarifying discussions on this issue. 


\section{Extensions}

This section discusses two extensions of our basic model. First, we add an employment benefit from attracting foreign firms. This is likely to be an important policy issue in practice. One approach to modelling this is to assume that workers in the $x$-industry receive a wage premium over what can be earned in the numeraire sector. ${ }^{25}$ Hence all households are employed, but the $x$-industry offers the "better" jobs. In this case there is an additional component to welfare maximization, as a wage premium from employment in the $x$-industry is added to consumer surplus and tax revenue. Even though the higher costs of producing good $x$ will reduce consumer surplus, this is more than compensated by the extra wage income. Hence each government has a stronger incentive to attract investment. This results in lower taxes, or higher subsidies, being paid in equilibrium, fully reflecting the additional benefit from hosting the mobile firms. One difference from the consumer surplus motive for attracting investment is that the wage premium will be (largely) independent of trade costs. Hence while economic integration reduces the ability of countries to tax location rents, it does not reduce their desire to attract firms for employment-related reasons.

However, in addition to consumer surplus, some other benefits from foreign direct investment will fall when trade costs decrease. For example, if the industry's product were a differentiated good and consumers had a liking for variety, reduced trade costs would give consumers increased access to those varieties produced in the other country. In a yet different setting where the $x$-industry produces a differentiated intermediate good, attracting additional firms would reduce aggregate transport costs borne by the final goods sector and increase this sector's competitiveness. In each of these cases the gains from attracting investment would decline with economic integration, as in the case of consumer surplus. Hence when any of these arguments is incorporated in the national welfare function, tax rates and welfare will continue to be a $U$-shaped function of trade costs, as in our benchmark analysis.

Secondly, we allow for the case where all firms are owned by the residents of countries $a$ and $b$, with shares in proportion to their population size. The appendix shows how local after-tax profit income is incorporated in the national welfare functions and derives

\footnotetext{
${ }^{25}$ The full analysis of this case is available from the authors upon request.
} 
the first-order conditions for nationally optimal tax rates. In this extended setting the algebra becomes very complex and uninstructive, however, when countries differ in size. We therefore rely on simulation analyses, using the same numerical specification as in Table 3 above. The results are given in Table 4 .

****** Table 4 about here $* * * * * *$

Table 4 shows that tax rates are generally lower in both countries as compared to the benchmark case (see Table 3). This is because the negative effect of taxes on after-tax profits is now partly borne by domestic residents. Nevertheless, the location-rent effect is still present since some part of the taxes levied by each country continues to fall on foreigners (the residents of the other country in the region). Hence, for sufficiently high trade costs, a positive tax remains optimal in both countries. Moreover, economic integration shows the familiar $U$-shaped pattern for welfare in both countries, as in our benchmark case. Note, however, that in our benchmark analysis economic integration hurts the countries in the region by reducing their ability to tax firm owners outside the region. This argument is no longer present when all firms are owned by residents of countries $a$ and $b$. Instead the critical effect is now that a fall in per-unit trade costs will lead to higher volumes of inefficient trade in equilibrium. Hence the total amount of wasteful trade costs first rises and then falls as trade costs are continuously reduced (see Brander and Krugman, 1983). For high level of trade costs, this effect dominates the pro-competitive effect of market integration and lowers welfare, whereas at low levels of trade costs a further reduction in these costs is unambiguously welfare-increasing. It also remains true that economic integration benefits the small country and hurts the large one for intermediate levels of trade costs. In fact, the parameter range where these conflicting welfare effects arise is enlarged, relative to our benchmark case in Table $3 .{ }^{26}$

\footnotetext{
${ }^{26}$ As in our benchmark analysis, it also seems to be the case here that countries do not want to reduce the number of active firms in equilibrium. While such a reduction would increase profit income, which now accrues to the residents of countries $a$ and $b$, this effect is dominated by reduced tax revenues and reduced consumer surplus in all the simulations that we have carried out.
} 


\section{Conclusion}

In this paper we have set up a simple model where two countries of different size compete for the location of an exogenously determined, but variable, number of profitmaking firms in an oligopolistic industry. In this model, economic integration leads to a $U$-shaped relationship between the degree of economic integration and the level of equilibrium taxes. A special feature of the model is that taxable location rents can arise even in an interior location equilibrium where firms are dispersed. At the same time national governments have the incentive to attract internationally mobile firms by means of subsidies in order to save on trade costs. These counteracting forces lead to non-monotonic effects of economic integration, with tax rates and welfare first declining and then rising again as trade costs are continuously reduced.

Another result of our model is that economic integration can simultaneously benefit small countries and harm large countries. This result may be relevant for several of the recent policy debates in the area of international tax coordination, such as the elimination of preferential tax regimes pursued simultaneously by the EU (Primarolo Report, 1999) and the OECD (2000). Many of these policy initiatives are led by large countries trying to counteract the effects of increasing economic integration, whereas they are targeted at small countries that are perceived to be the beneficiaries of continued economic integration.

Finally, the location rents that arise in our static model derive solely from the fact that firms will want to locate in different jurisdictions in order to reduce competition between them in the presence of trade costs. Each firm makes its location choice once and any subsequent relocation between host countries is not considered. An extended model could incorporate firm relocations, associated with positive relocation costs, in an intertemporal framework that distinguishes between initial location subsidies and profit taxation in a later period. Relocation costs would then add to the location rents that firms earn in their present location, increasing the taxing potential for host governments. It is known from the literature on tax holidays (e.g. Doyle and van Wijnbergen, 1994) that, when governments cannot commit to future policies, they compete more aggressively via location subsidies in the first period, as each government is aware of the advantage of attracting firms to its country when the investment is partially sunk. 
To the contrary, if economic integration were to reduce relocation costs over time, then initial investment subsidies may fall as there would be fewer profit taxes to be captured later. Incorporating these intertemporal aspects into a model of tax competition for a mobile industry is a challenging task for future research.

\section{Acknowledgements:}

We thank Rainald Borck, Marius Brülhart, Ben Ferrett, Panos Hatzipanayotou, Kai Konrad, Nic Schmitt, Alfons Weichenrieder and participants at the Asia Pacific Trade Seminar, Kobe, the European Trade Study Group, Athens, the Workshop on Fiscal Federalism, Sevilla, the German Economic Association Meetings, Munich and in seminars at the WZB Berlin, Munich, Nuremberg and Simon Fraser University, Vancouver, for helpful discussions. We also wish to acknowledge valuable comments from two anonymous referees and from the editor, Jonathan Eaton. This paper was started when the second author visited the Center for Economic Studies at the University of Munich and continued when the first author was visiting the University of Strathclyde. We thank both institutions for their hospitality. 


\section{Appendix}

\section{Derivation of equation set (19)}

Substituting (10), (11) and (13) in (12) and differentiating gives each country's best response function

$$
\begin{aligned}
& t_{a}=\frac{2 \tau^{2} k}{\beta[4(k+1)-n]}+\frac{\tau \mu\{(2 n-1)[2(k+1)-n]-n k\}}{\beta(k+1)[4(k+1)-n]}+t_{b} \frac{[2(k+1)-n]}{[4(k+1)-n]}, \\
& t_{b}=\frac{2 \tau^{2} k}{\beta[4(k+1)-u]}-\frac{\tau \mu\{(2 n-1)[2(k+1)-u]+u k\}}{\beta(k+1)[4(k+1)-u]}+t_{a} \frac{[2(k+1)-u]}{[4(k+1)-u]}
\end{aligned}
$$

where $\mu \equiv[2(\alpha-\omega)-\tau]>0$ and $u \equiv(1-n)$. Solving the set of simultaneous equations (A.1) yields the Nash equilibrium taxes in (19).

\section{Proof of Proposition 3}

Substituting (19) and (20) in country a's welfare function [eq. (12)] and differentiating with respect to $\tau$ gives

$$
\frac{\partial W_{a}}{\partial \tau}=\frac{\partial S_{a}}{\partial \tau}+t_{a} \frac{\partial k_{a}}{\partial \tau}+k_{a} \frac{\partial t_{a}}{\partial \tau} .
$$

Performing the derivations gives, in a first step

$$
\begin{gathered}
\frac{\partial W_{a}}{\partial \tau}=\frac{\tau\left[2 k_{a} k(k+1)+n k^{2}-n k_{a} k_{b}\right]-n k^{2}(\alpha-\omega)}{\beta(k+1)^{2}} \\
-\frac{t_{a}(2 n-1)(3 k+2)(\alpha-\omega)}{\tau^{2}(6 k+5)}+\frac{(2 n-1)(3 k+2)[2 k+2-n] k_{a}(\alpha-\omega-\tau)}{\beta(k+1)^{2}(6 k+5)},
\end{gathered}
$$

which reduces to (24) when $n=0.5$ and hence $k_{a}=k_{b}=k / 2$.

Evaluating (A.2) at $\tilde{\tau}$, as given in (25), yields

$$
\begin{gathered}
\left.\frac{\partial W_{a}}{\partial \tau}\right|_{\tilde{\tau}}=\frac{(\alpha-\omega)(2 n-1) \Omega_{a}}{\beta(k+1)^{2}(6 k+5)} \quad \text { where } \\
\Omega_{a} \equiv \frac{2 k(k+1)\left(12 k^{2}+33 k+18\right)}{8 k+11}+\frac{k(3 k+2)[n+(k+1)(4 n-1)]}{2}+\frac{(2 n-1)(8 k+9)^{2}}{4(8 k+11)(6 k+5)} \\
+\frac{(3 k+2)[2(k+1)-n]\left[k\left(48 k^{2}+82 k+35\right)-(2 n-1)\left(48 k^{2}+86 k+36\right)\right]}{2(6 k+5)(8 k+11)} .
\end{gathered}
$$

Since $\Omega_{a}>0$ for all $k>1$ and $n>0.5$ by assumption, it follows that $\partial W_{a} /\left.\partial \tau\right|_{\tilde{\tau}}>0$. 
For country $b$ we proceed analogously. Using (19) and (20) in $W_{b}$ [eq. (12)] and differentiating with respect to $\tau$ gives

$$
\frac{\partial W_{b}}{\partial \tau}=\frac{\partial S_{b}}{\partial \tau}-t_{b} \frac{\partial m}{\partial \tau}+(k-m) \frac{\partial t_{b}}{\partial \tau} .
$$

Performing the derivations yields

$$
\begin{gathered}
\frac{\partial W_{b}}{\partial \tau}=\frac{\tau\left[k_{b} k(2 k+2+n)+k_{a}^{2}(1-n)\right]-k(\alpha-\omega)\left[(1-n) k_{a}+n k_{b}\right]}{\beta(k+1)^{2}} \\
+\frac{t_{b}(2 n-1)(3 k+2)(\alpha-\omega)}{\tau^{2}(6 k+5)}-\frac{(2 n-1) k_{b}(\alpha-\omega-\tau)[2(k+1)+n(3 k+2)]}{\beta(k+1)^{2}(6 k+5)},
\end{gathered}
$$

which again reduces to (24) when $n=0.5$.

Evaluating (A.3) at $\tilde{\tau}$ gives

$$
\begin{gathered}
\left.\frac{\partial W_{b}}{\partial \tau}\right|_{\tilde{\tau}}=\frac{-(\alpha-\omega)(2 n-1) \Omega_{b}}{\beta(k+1)^{2}(6 k+5)} \quad \text { where } \\
\Omega_{b} \equiv \frac{24 k^{3}+19 k^{2}-2 k+2(1-n)(8 k+9)(3 k+2)\left(8 k^{2}+8 k-k_{a}\right)}{4(8 k+11)} \\
+\frac{(3 k+2)}{4}\left\{k[4(k+1)(2 n-1)+n]+\frac{(2 n-1)(8 k+9)[2(k+1)+n(3 k+2)]}{(6 k+5)}\right\} \\
+\frac{(8 k+7)[2(k+1)+n(3 k+2)] k_{a}}{8 k+11} .
\end{gathered}
$$

Since $\Omega_{b}>0$ from $k>1$ and $n>0.5$, it follows that $\partial W_{b} /\left.\partial \tau\right|_{\tilde{\tau}}<0$, as stated in (26).

\section{Section 5: Domestic firm ownership}

With domestic firm ownership allocated in proportion to population size, the welfare expressions for each country, inclusive of after-tax profit income, change to

$$
W_{a}=S_{a}+n k\left(\pi_{a}-t_{a}\right)+t_{a} k_{a}+n w ; \quad W_{b}=S_{b}+(1-n) k\left(\pi_{b}-t_{b}\right)+t_{b} k_{b}+(1-n) w
$$

where $S_{i}$ is given in (13), $\pi_{i}$ is in (9) and $k_{i}$ is in (11). Differentiating yields the following first-order conditions for optimal tax rates (in structural form):

$$
\begin{gathered}
t_{a}=\frac{\tau\left\{n k[\alpha-\omega-(2 n-1) \tau]+\tau k_{a}[2(k+1-n k)-n]\right\}}{\beta(k+1)^{2}} \\
t_{b}=\frac{\tau\left\{(1-n) k(\alpha-\omega)(1-4 n)+2 \tau k n(k+2-n)-\tau k_{a}(2 k n+n+1)\right\}}{\beta(k+1)^{2}}
\end{gathered}
$$

These values are used in the simulations of Table 4 . 


\section{References}

Baldwin, R.E., Krugman, P., 2004. Agglomeration, integration and tax harmonisation. European Economic Review 48, 1-23.

Bjorvatn, K., Eckel, C., 2006. Policy competition for foreign direct investment between asymmetric countries. European Economic Review 50, 1891-1906.

Black, D.A., Hoyt, W.E., 1989. Bidding for firms. American Economic Review 79, 1249-1256.

Borck, R., Pflüger, M., 2006. Agglomeration and tax competition. European Economic Review 50, 647-668.

Brander, J.A., Krugman, P., 1983. A 'reciprocal dumping' model of international trade. Journal of International Economics 15, 313-323.

Bucovetsky, S., 1991. Asymmetric tax competition. Journal of Urban Economics 30, $167-181$.

Burbidge, J., Cuff, C., Leach, J., 2006. Tax competition with heterogeneous firms. Journal of Public Economics 90, 533-549.

Davies, R.B., 2005. State tax competition for foreign direct investment: A winnable war? Journal of International Economics 67, 498-512.

de Mooij, R., Nicodème, G., 2008. Corporate tax policy and incorporation in the EU. International Tax and Public Finance 15, 478-498.

Devereux, M.P., Griffith, R., Klemm, A., 2002. Corporate income tax reforms and international tax competition. Economic Policy 35, 451-495.

Doyle, C., van Wijnbergen, S., 1994. Taxation of foreign multinationals: A sequential bargaining approach to tax holidays. International Tax and Public Finance 1, 211-225.

Ferrett, B., Wooton, I., 2005. Competing for a duopoly: international trade and tax competition. CEPR Discussion Paper 5379, London. 
Fuest, C., 2005. Economic integration and tax policy with endogenous foreign firm ownership. Journal of Public Economics 89, 1823-1840.

Fumagalli, C., 2003. On the welfare effects of competition for foreign direct investment. European Economic Review 47, 963-983.

Haaparanta, P., 1996. Competition for foreign direct investment. Journal of Public Economics 63, 141-153.

Haufler, A., Wooton, I., 1999. Country size and tax competition for foreign direct investment. Journal of Public Economics 71, 121-139.

Hines, J.R., 2007. Corporate taxation and international competition. In: A.J. Auerbach (ed.), Taxing corporate income in the 21st century. Cambridge University Press, 268-306.

Janeba, E., 1998. Tax competition in imperfectly competitive markets. Journal of International Economics 44, 135-153.

Kind, H.J., Midelfart Knarvik, K.H., Schjelderup, G., 2000. Competing for capital in a 'lumpy' world. Journal of Public Economics 78, 253-274.

OECD, 2000. Towards global tax co-operation. Progress in identifying and eliminating harmful tax practices. Paris.

OECD, 2007. Revenue statistics 1965-2006. http:/dx.doi.org/10.1787/100254446464.

Ottaviano G., van Ypersele, T., 2005. Market size and tax competition. Journal of International Economics 67, 25-46.

Primarolo Report, 1999. Report from the Code of Conduct Group to the ECOFIN Council. Brussels.

Tanzi, V., 1995. Taxation in an integrating world. The Brookings Institution, Washington, D.C.

Wilson, J.D., 1991. Tax competition with interregional differences in factor endowments. Regional Science and Urban Economics 21, 423-451. 